\title{
ANALISIS STRATEGI PENERAPAN KEBIJAKAN PENGELOLAAN LINGKUNGAN DI BERBAGAI EKOSISTEM DI KABUPATEN SERUYAN
}

\author{
ANALYSIS OF POLICY APPLICATION STRATEGY \\ MANAGEMENT OF THE ENVIRONMENT \\ IN VARIOUS ECOSYSTEMS IN SERUYAN DISTRICT
}

\author{
${ }^{1}$ Rajudinnor, ${ }^{2}$ Dedy Mulyadi \\ ${ }^{1}$ Staf Pengajar Program Studi Agribisnis Fakultas Pertanian Universitas Palangka Raya \\ ${ }^{2}$ Tenaga Ahli Teknik Sipil dan GIS PT. Geo Dinamika Utama Konsultan Palangka Raya \\ e-mail: rajudinnor@agb.upr.ac.id
}

\begin{abstract}
ABSTRAK
Penelitian ini bertujuan menganalisis faktor-faktor yang mempengaruhi kebijakan pengelolaan lingkungan di wilayah Kabupaten Seruyan dan menentukan strategi kebijakan pengelolaan lingkungan di berbagai ekosistem di wilayah Kabupaten Seruyan. Jenis penelitian ini adalah studi kasus. Metode analisis yang digunakan untuk menjawab tujuan pertama, yaitu Internal Strategi Factor Analysis Summary (IFAS) dan Ekternal Strategi Factor Analysis Summary (EFAS). Analisis untuk menjawab tujuan penelitian kedua digunakan analisis SWOT (Strength, Weakness, Oppurtunities, Threat). Hasil penelitian menunjukkan bahwa faktor-faktor yang dominan yang mempengaruhi kebijakan pengelolaan lingkungan hidup di berbagai ekosistem di wilayah Kabupaten Seruyan terdiri dari faktor internal (kekuatan dan kelemahan) dan faktor eksternal (peluang dan ancaman). Faktor kekuatan yaitu pemerintah Kabupaten Seruyan sudah memiliki perangkat SKPD yang lengkap untuk menjalankan roda pemerintahan dan penegakan aturan perundang-undangan Pemerintah sudah memilki aturan tentang kewajiban AMDAL, UKL dan UPL dan sudah pernah menerbitkan Surat Ijin lingkungan. Faktor kelemahan yaitu belum memiliki Perda RTRWK dan dokumen Kajian Lingkungan Strategis (KLHS) serta belum memiliki Rencana Detail Tata Ruang (RDTR) dan Bagian Wilayah Perencanaan (BWP), koordinasi antar sektor yang terlibat dalam pengelolaan sumberdaya alam dan lingkungan di wilayah Kabupaten Seruyan belum dilakukan secara optimal. Faktor peluang yaitu sering dilakukan kunjungan oleh pemerintah provinsi maupun oleh pemerintah pusat yang membidangi pengawasan dan lingkungan hidup, ada regulasi yang jelas untuk pengelolaan lingkungan hidup. Faktor ancaman yaitu pengawasan terhadap pelaksanaan pengelolaan lingkungan hidup di daerah oleh pemerintah provinsi maupun pemerintah pusat masih belum optimal dan partisipasi publik, transparansi, dan demokratisasi dalam menegakkan kebijakan tentang pengelolaan sumberdaya alam dan lingkungan sangat kurang, penegakan hukum administrasi terhadap pelanggaran aturan pengelolaan lingkungan hidup belum efektif dilakukan. Strategikebijakan pengelolaan lingkungan di berbagai ekosistem terdiri dari Strategi S-O, W-O, S-T, dan W-T. Berdasarkan nilai tertimbang koordinat yang diperoleh dari faktor internal dan eksternal ialah 0,900 dan 0,668 . Hasil analisis kuadrat SWOT berada pada kuadran 1, yaitu kuadran S-O mendukung strategi agresif, artinya bahwa kondisi yang ada punya potensi besar untuk melakukan optimalisasi pengelolaan lingkungan di berbagai ekosistem di wilayah Kabupaten Seruyan.
\end{abstract}

Kata kunci: Analisis strategi, kebijakan pengelolaan lingkungan 


\begin{abstract}
This study aims to analyze factors that influence environmental management policies and determine the environmental management policy strategies in various ecosystems district. This research is a case study. Methods used to answer the first objective, the Internal Strategy Factor Analysis Summary (IFAS) and the External Strategy Factor Analysis Summary (EFAS). To answer the second objective, we used SWOT (Strength, Weakness, Opportunities, Threat) analysis. Results showed that the dominant factors influenced environmental management policies in various ecosystems in the Seruyan District consisted of internal factors (strengths and weaknesses) and external factors (opportunities and threats). The strength factor is that the Seruyan District Government already has a complete SKPD tool to run government and enforcing the laws and regulations. The government also already has the rules about the 'AMDAL' (environmental impact assessment) requirements, the 'UKL' and 'UPL', and has already issued the environmental permit. In turn, the weaknesses factor, the government has not having the Regional Regulation on RTRWK and Strategic Environmental Assessment document (KLHS), Spatial Detail Plan (RDTR) and Regional Planning Section $(B W P)$. Further weaknesses are that the coordination between sectors involved in the management of the natural resources and the environment in the Seruyan District has not yet been carried out optimally. In addition, the opportunity factor is that visits and supervision are often carried out by the provincial government or by the central government that is in charge of supervision and the environment at least for every two months. In term environmental management, there are clear regulations applied. The threat factor is that the supervision on implementation of environmental management of current area by provincial and central government is still yet not optimal, and public participation, transparency, and democratization to enforce policies on natural resource management and the environment is very lacking. Similarly, the administrative law enforcement of violations of environmental management rules has not yet been effectively done. Environmental management policy strategies in various ecosystems consist of $S-O, W-O, S-T$, and $W-T$ Strategies. Based on the weighted values of the coordinates obtained from internal and external factors are respectively 0.900 and 0.668 . The SWOT quadratic analysis on quadrant 1, namely the $S-O$ quadrant support an aggressive strategy, meaning that the existing conditions have great potential to optimize environmental management in various ecosystems in the Seruyan District.
\end{abstract}

Keywords: Environmental management policy, strategy analysis

\section{PENDAHULUAN}

\section{Latar Belakang}

Kabupaten Seruyan adalah salah satu wilayah kabupaten dari 13 kabupaten dan kota yang ada di Kalimantan Tengah. Kabupaten Seruyan merupakan wilayah kabupaten hasil pemekaran wilayah dari kabupaten Kotawaringin Timur berdasrkan Undang-Undang Nomor 5 Tahun 2002 tentang Pembentukan Kabupaten Katingan, Kabupaten Seruyan, Kabupaten Sukamara, Kabupaten Lamandau, Kabupaten Pulang
Pisau, Kabupaten Gunung Mas, Kabupaten Murung Raya, dan Kabupaten Barito Timur di Provinsi Kalimantan Tengah (Lembaran Negara Republik Indonesia Tahun 2002 Nomor 18, Tambahan Lembaran Negara Nomor 4180). Luas wilayah Kabupaten Seruyan $\pm 16.404 \mathrm{Km}^{2}$ $(11,6 \%$ dari luas wilayah Kalimantan Tengah).

Sejak dilakukan pembentukan Kabupaten Seruyan, hingga saat ini belum ada Peraturan Daerah tentang Rencana Tata Ruang Wilayah Kabupaten Seruyan 
(Perda RTWK) dan belum memiliki Kajian Lingkungan Hidup Strategis (KLHS). Kedua dokumen penting ini masih dalam proses penyusunan. (Bappeda Kabupaten Seruyan 2018). Undang-Undang Penataan Ruang Nomor 6 Tahun 2007 dan UndangUndang Perlindungan dan Pengelolaan Lingkungan Hidup Nomor 32 tahun 2009 menyatakan bahwa RTRWK dan KLHS adalah dokumen utama sebagai acuan pembangunan di daerah Kota dan Kabupaten. KLHS adalah rangkaian analisis yang sistematis, menyeluruh, dan partisipatif untuk memastikan bahwa prinsip pembangunan berkelanjutan telah menjadi dasar dan terintegrasi dalam pembangunan suatu wilayah dan/atau kebijakan, rencana, dan/atau program.

Kabupaten Seruyan yang saat ini sedang berkembang sangat diuntungkan dengan melimpahnya sektor perkebunan kelapa sawit. Pada tahun 2017 tercatat jumlah Perusahaan Besar Swasta (PBS) yang berinvestasi di perkebunan kelapa sawit dan sudah operasional di wilayah Kabupaten Seruyan sebanyak 37 perusahaan dengan luas areal perkebunan untuk PBS sebesar 451.752,47 $\mathrm{Ha}$ $(27,05 \%$ dari luas wilayah Kabupaten Seruyan 1.670.040,76 Ha). Selain itu tercatat luas perkebunan kelapa sawit rakyat seluas $54.230,36 \mathrm{Ha}(3,25 \%$ dari luas wilayah Kabupaten Seruyan). Pertumbuhan ekonomi Kabupaten Seruyan pada tahun 2017 sebesar 5,15\%. Sementara pertumbuhan penduduk pada tahun yang sama tercatat sebesar $4,3 \%$ (BPS Kabupaten Seruyan, 2018).

Pembangunan sektor ekonomi di wilayah Kabupaten Seruyan sama halnya dengan pembangunan di daerah lain sudah tentu menimbulkan dampak positif dan negatif bagi lingkungan hidup.

Undang-Undang Perlindungan dan Pengelolaan Lingkungan Hidup Nomor 32 tahun 2009 menyatakan bahwa semangat otonomi daerah dalam penyelenggaraan pemerintahan Negara Kesatuan Republik Indonesia telah membawa perubahan hubungan dan kewenangan antara Pemerintah dan pemerintah daerah, termasuk di bidang perlindungan dan pengelolaan lingkungan hidup. Bahwa kualitas lingkungan hidup yang semakin menurun telah mengancam kelangsungan perikehidupan manusia dan mahluk hidup lainnya sehingga perlu dilakukan perlindungan dan pengelolaan lingkungan hidup yang sungguh-sungguh dan konsisten oleh semua pemangku kepentingan.

Sejauhmana optimalisasi strategi penerapan kebijakan pengelolaan lingkungan hidup di berbagai ekosistem di wilayah Kabupaten Seruyan perlu dilakukan studi dan kajian untuk memperoleh data sebagai dasar membuat strategi kebijakan dalam perlindungan dan pengelolaan lingkungan yang berorientasi kepada kesejahteraan rakyat.

\section{Rumusan Masalah}

Berdasarkan hasil penelitian sebelumnya yang dilakukan oleh Rajudinnor dan Mulyadi (2018), ditemukan banyak permasalahan lingkungan hidup yang ada di wilayah Kabutaen Seruyan terutama yang berhubungan dengan perangkat regulasi yang belum cukup tersedia dan masalah aplikasi penerapan kebijakan perlindungan dan pengelolaan lingkungan yang masih belum optimal. Diantara masalah-masalah yang berhubungan dengan perlindungan dan pengelolaan lingkungan di wilayah Kabupaten Seruyan adalah:

1. Belum melakukan inventarisasi potensi dan kerusakan lingkungan hidup pada berbagai ekosistem terutama ekosistem darat dan ekosistem perairan.

2. Belum melakukan penetapan Ekoregion di wilayah Kabupaten Seruyan. (Ekoregion adalah wilayah geografis yang memiliki kesamaan ciri iklim, tanah, air, flora, dan fauna asli, serta pola interaksi manusia dengan alam yang menggambarkan integritas sistem alam dan lingkungan hidup 
(Undang-Undang Nomor 32 Tahun 2009)).

3. Belum pernah melakukan kegiatan bimbingan teknis tentang Tata Ruang dan KLHS bagi SKPD di lingkup pemerintah Kabupaten Seruyan.

4. Masih proses penyusunan Perda RTRWK dan dokumen KLHS serta belum memiliki Rencana Detail Tata Ruang (RDTR) dan Bagian Wilayah Perencanaan (BWP).

5. Koordinasi antar sektor yang terlibat dalam pengelolaan sumberdayaalam dan lingkungan di wilayah Kabupaten Seruyan belum dilakukan secara optimal.

Berdasarkan masalah-masalah tersebut dirumuskan masalah utama pada penelitian ini sebagai berikut:

1. Apa saja faktor internal dan eksternal yang mempengaruhi kebijakan pngelolaan lingkungan di wilayah Kabupaten Seruyan?

2. Bagaimana strategi yang tepat dalam melakukan optimalisasi perlindungan dan pengelolaan lingkungan hidup di berbagai ekosistem di wilayah Kabupaten Seruyan?

\section{Tujuan Penelitian}

Tujuan penelitian ini adalah:

1. Menganalisis faktor-faktor yang mempengaruhi kebijakan pengelolaan lingkungan di wilayah Kabupaten Seruyan.

2. Menentukan strategi kebijakan pengelolaan lingkungan di berbagai ekosistem di wilayah Kabupaten Seruyan.

\section{METODE PENELITIAN}

\section{Jenis Penelitian}

Jenis penelitian ini adalah penelitian studi kasus.Pertimbangan studi kasus adalah karena memiliki karakteristik khusus. Kabupaten Seruyan adalah satusatunya wilayah kabupaten hasil pemekaran dari Kabupaten Kotawaringin
Timur sejak tahun 2002 hingga saat penelitian ini dilakukan belum memiliki Peraturan Daerah Rencana Tata Ruang Wilayah Kabupaten (RTRWK) dan belum memiliki perangkat regulasi yang lengkap tentang pengelolaan lingkungan hidup termasuk belum memiliki dokumen Kajian Lingkungan Hidup Startegis (KLHS). KLHS adalah kajian yang harus dilakukan pemerintah daerah sebelum memberikan izin pengelolaan lahan maupun hutan. Pembuatan KLHS ditujukan untuk memastikan penerapan prinsip pembangunan berkelanjutan dalam pembangunan suatu wilayah, serta penyusunan kebijakan dan program pemerintah.

\section{Metode Pengumpulan Data}

Metode pengumpulan data menggunakan teknik wawancara terstruktur dengan menggunakan daftar pertanyaan (kuisioner) dan metode penelaahan kepustakaan. Metode atau teknik wawancara, yaitu dengan menggali data melalui wawancara dengan responden yang dipilih.Sedangkanmetode penelaahan kepustakaan yaitu metode pengumpulan data yang dilakukan dengan cara mengutip atau mengambil data dari sumber pustaka atau sumber yang sudah diolah oleh pihak lain.

Data yang dikumpulkan terdiri dari data primer dan data sekunder. Data primer terdiri dari data dari responden, peta administrasi, dan informasi tata ruang Kabupaten Seruyan, data hasil wawancara tentang optimalisasi penerapan kebijakan pengelolaan lingkungan di berbagai ekosistem di Kabupaten Seruyan. Sedangkan data sekunder terdiri dari data yang terkait dengan gambaran umum Kabupaten Seruyan seperti data geografi, data demografi, data ekonomi serta prasarana wilayah.

Analisis SWOT adalah identifikasi berbagai faktor secara sistematis untuk merumuskan strategi kebijakan. Analisis ini didasarkan pada logika yang dapat 
memaksimalkan kekuatan (strength) dan peluang (oppurtunities), namun secara bersamaan dapat meminimalkan kelemahan (weakness) dan ancaman (threat).

Dalam studi ini mereka yang dijadikan informan kunci adalah berasal dari unsur ekskutif (Bupati dan Kepala SKPD), unsur legislatif (DPRD), dan unsur yudikatif (Kepolisian dan Kejaksaan) di wilayah pemerintahan Kabupaten Seruyan. Data sekunder diperoleh dari instansi pemerintah Kabupaten Seruyan dan pemerintah Provinsi Kalimantan Tengah (BPS, Bappeda, BLH, Bagian Tata Ruang Dinas PUPR).

\section{Analisis Data Penelitian}

Metode analisis yang digunakan untuk menjawab tujuan pertama penelitian yaitu mengetahui faktor-faktor yang mempengaruhi kebijakan pengelolaan lingkungan di wilayah Kabupaten Seruyan digunakan Internal Strategi Factor Analysis Summary (IFAS) dan Ekternal
Strategi Factor AnalysisSummary (EFAS). Pada analisis IFAS dan EFAS masingmasing faktor kekuatan, kelemahan, peluang dan ancaman diberi kategori nilai, yaitu 1 = sangat tidak setuju, $2=$ tidak setuju, $3=$ ragu-ragu, $4=$ setuju, $5=$ sangat setuju. Selanjutnya untuk menentukan bobot adalah masing-masing nilai kategori dibagi dengan total nilai kategore. Selanjutnya ditentukan skala rating skala 1 sampai 4. Nilai kategori dikalikan dengan nilai rating diperoleh nilai skor dari masing-masing kekuatan, kelemahan, peluang dan ancaman. Skor tertinggi adalah faktor yang paling berpengaruh terhadap kebijakan pengelolaan lingkungan (Rangkuti, 2006).

Untuk menjawab tujuan kedua, yaitu menentukan strategi kebijakan pengelolaan lingkungan di berbagai ekosistem di Kabupaten Seruyan digunakan analisis SWOT. Strategi yang dianalisis adalah strategi S-O, strategi WO, strategi S-T dan strategi W-T. (Rangkuti, 2006).

Tabel 1. Matriks SWOT (Strenghts, Opportunities, Weakness, Threats)

\begin{tabular}{ccc} 
IFAS & $\begin{array}{c}\text { Strengths (S) } \\
\text { Menentukan 5-10 faktor } \\
\text { kekuatan internal }\end{array}$ & $\begin{array}{c}\text { Weakness (W) } \\
\text { Menentukan 5-10 faktor } \\
\text { kelemahan internal }\end{array}$ \\
\hline $\begin{array}{c}\text { Menentukan 5-10 faktor } \\
\text { peluang eksternal }\end{array}$ & $\begin{array}{c}\text { Strategi S-O } \\
\text { Membuat strategi yang } \\
\text { menggunakan kekuatan } \\
\text { untuk memanfaatkan } \\
\text { peluang }\end{array}$ & $\begin{array}{c}\text { Strategi W-O } \\
\text { Membuat strategi }\end{array}$ \\
yangmeminimalkan kelemahan \\
untuk memenfaatkan peluang
\end{tabular}

Sumber: Rangkuti, 2016.

\section{HASIL DAN PEMBAHASAN}

\section{Hasil Analisis IFAS dan EFAS}

\section{Faktor kekuatan dan kelemahan}

Hasil penelitian terhadap analisis aspek IFAS diketahui bahwa skor tertinggi terhadap faktor kekuatan yaitu Pemerintah Seruyan sudah memiliki perangkat SKPD yang lengkap untuk menjalankan roda pemerintahan dan penegakan aturan perundang-undangan dengan nilai skor 0,332. Sedangkan skor terendah pada faktor kekuatan terjadi yaitu sudah memilki aturan tentang kewajiban AMDAL, UKL dan UPL. Sudah pernah menerbitkan Surat Ijin Lingkungan dengan nilai skor sebesar 0,201. Selanjutnya skor tertinggi pada faktor kelemahan yaitu: belum memiliki Perda RTRWK dan 
dokumen KLHS serta belum memiliki Rencana Detail Tata Ruang (RDTR) dan Bagian Wilayah Perencanaan (BWP), dengan nilai skor 0,166 . Sedangkan skor terendah untuk faktor kelemahan yaitu koordinasi antar sektor yang terlibat dalam pengelolaan sumberdaya alam dan lingkungan di wilayah Kabupaten Seruyan belum dilakukan secara optimal, dengan nilai skor 0,083 .

\section{Faktor Peluang dan ancaman}

Hasil penelitian terhadap analisis aspek EFAS diketahui bahwa skor tertinggi pada peluang yaitu sering dilakukan kunjungan oleh pemerintah provinsi ataupun oleh pemerintah pusat yang membidangi pengawasan dan lingkungan hidup ke wilayah Kabupaten Seruyan dalam rangka pengawasan dan pembinaan aparat di wilayah Kabupaten Seruyan dengan nilai skor 0,400. Sedangkan skor terendah pada peluang yaitu ada regulasi yang jelas dari pemerintah provinsi dan pemerintah pusat untuk pengelolaan lingkungan hidup dengan skor 0,180. Selanjutnya skor tertinggi pada faktor ancaman yaitu pengawasan terhadap pelaksanaan pengelolaan lingkungan hidup di daerah oleh pemerintah provinsi maupun pemerintah pusat masih belum optimal. Partisipasi publik, transparansi, dan demokratisasi dalam menegakkan kebijakan tentang pengelolaan sumberdaya alam dan lingkungan sangat kurang dengan masing-masing nilai skor 0,160. Sedangkan skor terendah pada faktor ancaman yaitu penegakan hukum administrasi terhadap pelanggaran aturan pengelolaan lingkungan hidup belum efektif dilakukan, dengan nilai skor 0,080 .

\section{Hasil Analisis SWOT}

Penerapan keempat strategi (S-O, S-T, W-O, dan W-T) memiliki langkah yang berbeda-beda sesuai tujuan dan maksud untuk mengatasi kelemahan dan ancaman serta meningkatkan kekuatan dan peluang. Beberapa strategi hasil analisis SWOT dalam optimalisasi pengelolaan lingkungan di berbagai ekosistem di Kabupaten Seruyan sebagaimana pada Lampiran 3, adalah sebagai berikut:

\section{Strategi S-O}

$$
\text { Strategi }
$$

$$
\text { S-O }
$$

(Strength-

Opportunity) atau strategi kekuatan peluang adalah strategi yang menggunakan kekuatan internal untuk memanfaatkan peluang eksternal. Alternatif Strategi S-O yaitu:

1. Memperkuat koordinasi dan optimalisasi peran dan fungsi SKPD dalam pengelolaan lingkungan serta mempertegas penerapan sangsi terhadap pelanggaran aturan dan penegakan hukum.

2. Komitment dalam melaksanakan hasil koordinasi dan penerapan regulasi dalam pengelolaan lingkungan.

3. Fasilitasi investasi dan optimalisasi pelayanan tanpa ada bargaining dalam penegakan aturan.

4. Tindak lanjut hasil pengawasan dan kunjungan instasi propinsi dan pusat dalam perbaikan pengelolaan lingkungan.

5. Penyusunan laporan dan tindak lanjut hasil kunjungan instansi pengawasan tingkat pusat dan tingkat provinsi untuk optimalisasi pelaksanaan pengelolaan lingkungan di berbagai ekosistem di wilayah Kabupaten Seruyan.

\section{Strategi W-O}

Strategi W-O (WeaknessOppurtunity) atau strategi kelemahanpeluang adalah untuk meminimalkan kelemahan yang ada untuk memanfaatkan peluang eksternal. Alternatif strategi W-O yaitu:

1. Segera menyusun rencana dan melakukan inventarisasi potensi dan kerusakan lingkungan hidup pada ekosistem darat dan ekosistem perairan di wilayah kebupaten Seruyan.

2. Segera dilakukan penetapan Ekoregion di wilayah Kabupaten Seruyan dengan mengacu kepada regulasi yang ada. 
3. Melakukan kegiatan bimbingan teknis tentang Tata Ruang dan KLHS bagi SKPD di lingkup pemerintah Kabupaten Seruyan.

4. Implementasi Rencana RTRWK, KLHS dan melakukan penyusunan RDTR pada masing-masing BWP di Kabupaten Seruyan.

5. Pengendalian pencemaran lingkungan hidup, bertujuan untuk mengurangi kemerosotan mutu dan fungsi lingkungan hidup yang disebabkan oleh makin meningkatnya kegiatan pembangunan.

\section{Strategi S-T}

Strategi S-T (Strength-Threat) atau strategi kekuatan-ancaman adalah strategi untuk mengoptimalkan kekuatan internal yang dimiliki dalam mengantisipasi ancaman. Alternatif strategi yaitu:

1. SKPD terkait harus komitmen dalam ketaatan aturan termasuk memperhatikan ketentuan RTRWK untuk pemberian izin investasi di wilayah Kabupaten Seruyan.

2. Instansi pengawasan harus melakukan kegiatan pengawasan secara ketat dengan penerapan sangsi yang tegas kepada pelanggar aturan.

3. Optimalisasi pengendalian pencemaran lingkungan hidup untuk mengurangi kemerosotan mutu dan fungsi lingkungan hidup perairan darat dan laut, tanah, dan udara yang disebabkan oleh makin meningkatnya kegiatan pembangunan.

4. Penerapan sangsi hukum baik berupa sanksi administrasi maupun sanksi pidana wajib diterapkan bagi pelanggar aturan dalam pengelolaan lingkungan.

5. Optimalisasi kegiatan penyuluhan dan pelibatan masyarakat dalam pengawasan pengelolaan lingkungan di wilayah Kabupaten Seruyan.

\section{Strategi W-T}

Strategi W-T (Weakness-Threat) atau strategi kelemahan-ancaman adalah strategi meminimalkan kelemahan internal dan menghindari ancaman eksternal. Alternatif strategi, yaitu:

1. Penetapan Baku Mutu lingkungan hidup (Environmental quality standart) dilakukan dengan mengacu kepada Kriteia Baku Mutu Lingkungan Hidup tingkat nasional, tingkat provinsi dan disesuaikan dengan kriteria/kondisi tingkat kabupaten yang selanjutnya ditetapkan dengan Peraturan Daerah Kabupaten Seruyan. Supremasi hukum terhadap pelanggaran aturan pengelolaan lingkungan hidup harus dilakukan secara jelas dan nyata.

2. Peningkatan aktivitas pengawasan oleh instasi terkait terhadap kegiatan pengelolaan lingkungan hidup oleh sektor swasta dan pemerintah di wilayah Kabupaten Seruyan harus lebih efektif dilakukan.

3. Penguatan kelembagaan melalui alokasi pendanaan, pendidikan dan pelatihan dalam upaya peningkatan kualitas sumberdaya manusia untuk pengelolaan lingkungan hidup di wilayah Kabupaten Seruyan.

4. Peningkatan peran serta masyarakat dan dunia usaha dalam upaya pengelolaan sumberdaya alam dan lingkungan hidup melalui pola kemitraan.

Setelah diperoleh analisis SWOT, untuk mempertajam analisis dapat digunakan kuadran SWOT untuk mengetahui prioritas strategi dan alternatif strategi yang diperoleh sehingga dapat diterapkan lebih optimal. Untuk memperoleh titik koordinat faktor kekuatan, kelemahan, peluang, dan ancaman dengan cara menjumlahkan nilai skor hasil analisis IFAS dan EFAS. 
Tabel 2. Titik Koordinat Kuadran SWOT untuk Optimalisasi Pengelolaan Lingkungan di Berbagai Ekosistem di Wilayah Kabupaten Seruyan

\begin{tabular}{clc}
\hline No. & \multicolumn{1}{c}{ Faktor Internal } & Jumlah Skor \\
\hline 1. & (+) Kekuatan & 1,251 \\
\hline 2. & (-) Kelemahan & $-0,583$ \\
\hline & Jumlah (Kekuatan + Kelemahan) & 0,668 \\
\hline No. & $\quad$ Faktor Eksternal & Jumlah Skor \\
\hline 1. & (+) Peluang & 1,520 \\
\hline 2. & (-) Ancaman & $-0,620$ \\
\hline & Jumlah (Peluang + Ancaman) & 0,900 \\
\hline
\end{tabular}

Sumber: Hasil Pengolahan Data, Tahun 2019.

Berdasarkan Tabel 2, dapat digambarkan dalam diagram SWOT berikut.

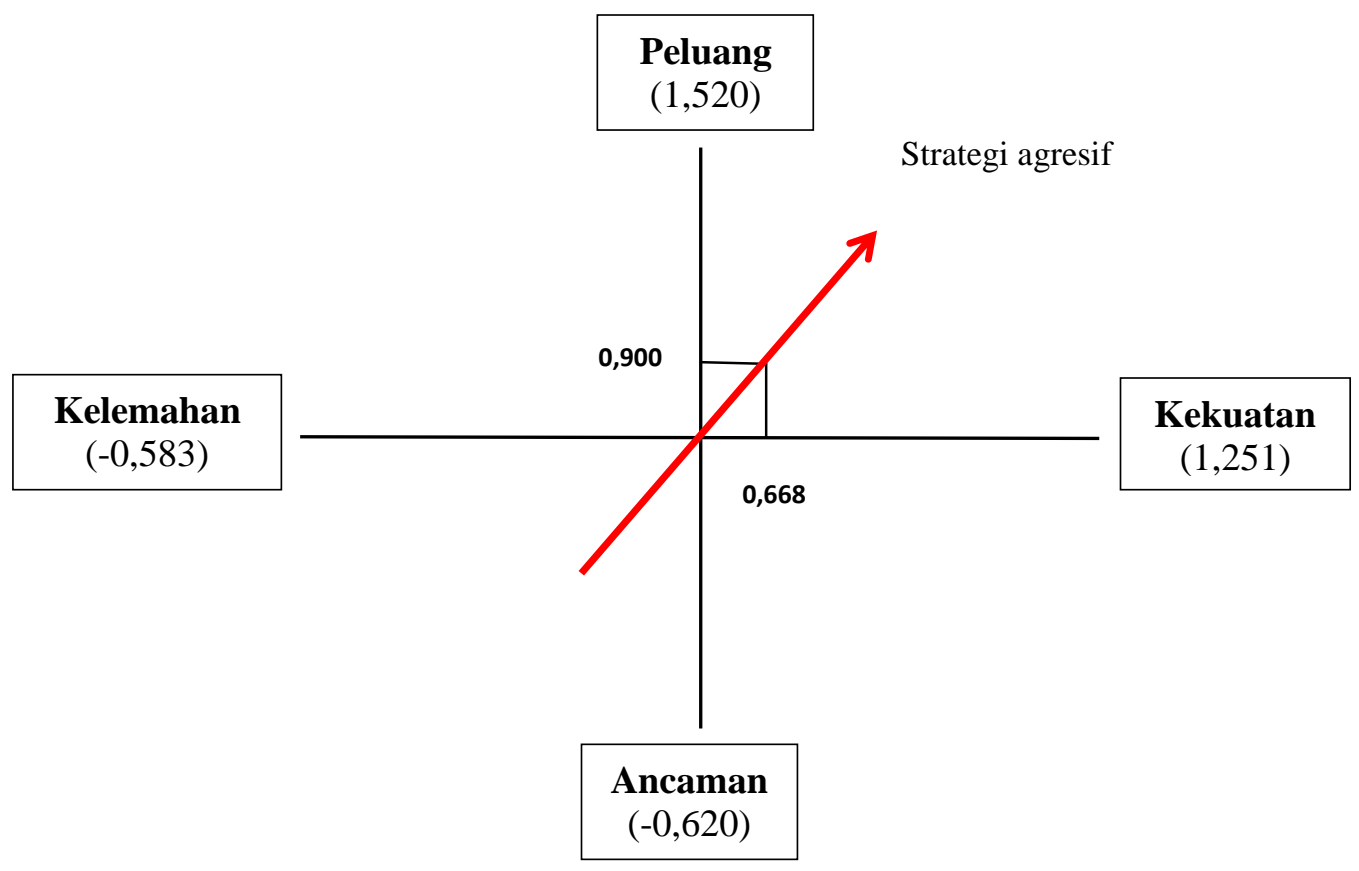

Gambar 1. Diagram Hasil Analisis Kuadran SWOT

Bedasarkan hasil analisis kuadran SWOT diketahui bahwa kondisi pengelolaan lingkungan hidup di wilayah Kabupaten Seruyan. Berdasarkan nilai tertimbang diperoleh nilai koordinat $(0,900 ; 0,668)$ yang berada di kuadran 1 , yaitu pada kuadran strategi $\mathrm{S}-\mathrm{O}$ yang mendukung strategi agresif. Arah perkembangan garis terlihat normal dengan hasil titik koordinat mendekati titik keseimbangan antara faktor peluang dan faktor kekuatan. Mendukung strategi agresif artinya bahwa kondisi yang ada punya potensi besar untuk melakukan optimalisasi pengelolaan lingkungan di berbagai ekosistem di wilayah Kabupaten Seruyan.

\section{KESIMPULAN DAN SARAN}

\section{Kesimpulan}

Berdasarkan hasil penelitian ini diperoleh kesimpulan, sebagai berikut:

1. Faktor-faktor dominan yang 
mempengaruhi kebijakan pengelolaan lingkungan hidup di berbagai ekosistem di wilayah Kabupaten Seruyan terdiri dari faktor internal (kekuatan dan kelemahan) dan faktor eksternal (peluang dan ancaman). Faktor kekuatan yaitu: pemerintah Kabupaten Seruyan sudah memiliki perangkat SKPD yang lengkap untuk menjalankan roda pemerintahan dan penegakan aturan perundang-undangan Pemerintah sudah memilki aturan tentang kewajiban AMDAL, UKL dan UPL dan sudah pernah menerbitkan Surat Ijin lingkungan sebanyak 19 buah. Faktor kelemahan yaitu: belum memiliki Perda RTRWK dan dokumen Kajian Lingkungan Strategis (KLHS) serta belum memiliki Rencana Detail Tata Ruang (RDTR) dan Bagian Wilayah Perencanaan (BWP), koordinasi antar sektor yang terlibat dalam pengelolaan sumberdaya alam dan lingkungan di wilayah Kabupaten Seruyan belum dilakukan secara optimal. Faktor peluang yaitu: sejak tahun 2018 hingga tahun 2019 sering dilakukan kunjungan (tiap dua bulan sekali) oleh pemerintah provinsi ataupun oleh pemerintah pusat yang membidangi pengawasan dan lingkungan hidup, ada regulasi yang jelas dari pemerintah provinsi dan pemerintah pusat untuk pengelolaan lingkungan hidup. Faktor ancaman yaitu: pengawasan terhadap pelaksanaan pengelolaan lingkungan hidup di daerah oleh pemerintah provinsi maupun pemerintah pusat masih belum optimal. Partisipasi publik, transparansi, dan demokratisasi dalam menegakkan kebijakan tentang pengelolaan sumberdaya alam sangat kurang. penegakan hukum administrasi terhadap pelanggaran aturan pengelolaan lingkungan hidup belum efektif dilakukan.

2. Strategi kebijakan pengelolaan lingkungan di berbagai ekosistem di wilayah Kabupaten Seruyan terdiri dari Strategi S-O, W-O, S-T, dan W-T. Berdasarkan nilai tertimbang koordinat yang diperoleh dari faktor internal dan eksternal ialah 0,900 dan 0,668. Hasil analisis kuadran SWOT berada pada kuadran 1, yaitu kuadran S-O mendukung strategi agresif. Arah perkembangan garis terlihat normal dengan hasil titik koordinat mendekatai titik keseimbangan antara factor peluang dan faktor kekuatan. Mendukung strategi agresif artinya bahwa kondisi yang ada punya potensi besar untuk melakukan optimalisasi pengelolaan lingkungan di berbagai ekosistem di wilayah Kabupaten Seruyan.

\section{Saran}

1. Kepada Pemerintah Kabupaten Seruyan segera melakukan strategi optimalisasi penerapan kebijakan pengelolaan lingkungan hidup melalui implementasi Rencana Tata Ruang Wilayah Kabupaten dan Kajian Lingkungan Hidup Strategis. Strategi kebijakan pengelolaan lingkungan hendaknya mengacu kepada hasil analisis SWOT yaitu strategi Strategi S-O, W-O, S-T, dan W-T.

2. Kepada instansi pengawasan baik tingkat Provinsi Kalimantan Tengah maupun tingkat pusat agar lebih efektif melakukan pengawasan dan memberikan solusi dalam hal perlindungan dan pengelolaan lingkungan hidup di wilayah Kabupaten Seruyan.

3. Kepada pihak investor (perusahaan) dan masyarakat di wilayah Kabupaten Seruyan agar meningkatkan partisipasinya dalam kegiatan pembangunan Kabupaten Seruyan dan dalam memelihara kelestraian lingkungan di berbagai ekosistem di wilayah Kabupaten Seruyan.

4. Kepada kalangan akademisi dan perguruan tinggi kiranya dapat 
melakukan kajian dan kerjasama dengan pemerintah Kabupaten Seruyan dan dapat memberikan informasi data dan solusi kebijakan untuk kemajuan pembangunan dan pelestarian lingkungan hidup khususnya di wilayah Kabupaten Seruyan.

\section{DAFTAR PUSTAKA}

Badan Perencanaan Pembangunan Daerah Kabupaten Seruyan. (2019). Draft Rencana Tata Ruang Wilayah Kabupaten Seruyan 2018-2038.

Choirunnisak. (2012). Penerapan Analisis SWOT Dalam Strategi Pemasaran Produk Tabungan Pada BMI Cabang Pembantu Magelang.

David, Fred R. (2018). Manajemen Strategi. Jakarta: Penerbit Salemba Empat.

Eddy, Karden. (2019). Pengelolaan Lingkungan Hidup. Jakarta: Penerbit Djambatan.

https://cpssoft.com/blog/bisnis/pengertiananalisis-swot/Analisis SWOT: Pengertian, Metode Analisis dan
Contohnya. Diakses 24 Desember 2019.

http://www.jdih.kemenkeu.go.id/fullText/2 009/32TAHUN2009UU.HTM.Und ang-Undang Nomor 32 Tahun 2009 tentang Perlindungan dan PengelolaanLingkungan Hidup. Diakses 24 Desember 2019.

Manik. (2016). Pengelolaan Lingkungan Hidup. Jakarta: Penerbit Prenada Media Group, Kencana.

Rajudinnor dan Mulyadi, Dedy. (2018). Kajian Studi Tata Ruang dan Optimalisasi Pengelolaan Lingkungan di Kabupaten Seruyan. Rangkuti, Freddy. (2006). Analisis SWOT Teknik Membedah Kasus Bisnis. Jakarta: PT Gramedia Pustaka Utama.

Salim, Emil. (2018). Pembangunan Berwawasan Lingkungan. Jakarta: LP3ES.

Soemarwoto, Otto. (2001). Paradigma Baru Pengelolaan Lingkungan Hidup. Yogyakarta: Gadjah Mada University Press. 
Lampiran 1. Tabel Analisis IFAS

\begin{tabular}{|c|c|c|c|c|}
\hline \multirow{2}{*}{\multicolumn{5}{|c|}{$\frac{\text { Faktor Strategi Internal (IFAS) }}{\text { Kekuatan }}$}} \\
\hline & & & & \\
\hline 1. & $\begin{array}{l}\text { Pemerintah Seruyan sudah memiliki perangkat SKPD yang lengkap untuk } \\
\text { menjalankan roda pemerintahan dan penegakan aturan perundang-undangan. }\end{array}$ & 0,083 & 4 & 0,332 \\
\hline 2. & $\begin{array}{l}\text { Sudah sering melakukan koordinasi antar SKPD dan dunia usaha dalam } \\
\text { pengelolaan lingkungan }\end{array}$ & 0,067 & 4 & 0,268 \\
\hline 3. & Sudah memilki aturan tentang kewajiban AMDAL UKL dan UPL. & 0,067 & 3 & 0,201 \\
\hline 4. & $\begin{array}{l}\text { Sudah pernah menerbitkan Surat Ijin lingkungan sebanyak } 19 \text { buah (swasta } \\
7 \text { buah, pemerintah } 7 \text { buah, dan koperasi } 5 \text { buah). }\end{array}$ & 0,067 & 3 & 0,201 \\
\hline \multirow[t]{3}{*}{5.} & $\begin{array}{l}\text { Kabupaten Seruyan memliki potensi sumberdaya alam di berbagai sektor } \\
\text { perekonomian (potensi lahan untuk perkebunan,potensi tambang biji besi, } \\
\text { dan pasir kuarsa, potensi perairan dan perikanan, potensi burung wallet, dan } \\
\text { lain-lain. }\end{array}$ & 0.083 & 3 & 0,249 \\
\hline & Jumlah & $\mathbf{0 , 2 8 4}$ & & 1,251 \\
\hline & Kelemahan & Bobot & Rating & Skor \\
\hline 1. & $\begin{array}{l}\text { Belum dilakukan inventarisasi potensi dan kerusakan lingkungan hidup } \\
\text { pada ekosistem darat dan ekosistem perairan }\end{array}$ & 0,050 & 2 & 0,100 \\
\hline 2. & $\begin{array}{l}\text { Belumdlakukan penetapanEkoregiondi } \\
\text { wilayahkabupatenSeruyan.(Ekoregionadalahwilayahgeografisyangmemiliki } \\
\text { kesamaan ciriiklim,tanah,air,flora,dan } \\
\text { faunaasli,sertapolainteraksimanusiadenganalamyangmenggambarkan } \\
\text { integritassistem alamdanlingkunganhidup(UUNo.32Tahun2009)). }\end{array}$ & 0,050 & 2 & 0,100 \\
\hline 3. & $\begin{array}{l}\text { Belum pernah melakukan kegiatan bimbingan teknis tentang Tata Ruang } \\
\text { dan KLHS bagi SKPD di lingkup pemerintah Kabupaten Seruyan }\end{array}$ & 0,067 & 2 & 0,134 \\
\hline & $\begin{array}{l}\text { Belum memiliki Perda RTRWK dan dokumen KLHS serta belum memiliki } \\
\text { Rencana Detail Tata Ruang (RDTR) dan Bagian Wilayah Perencanaan } \\
\text { (BWP). }\end{array}$ & 0,083 & 2 & 0,166 \\
\hline & $\begin{array}{l}\text { Koordinasi antar sektor yang terlibat dalam pengelolaan sumberdaya alam } \\
\text { dan lingkungan di wilayah Kabupaten Seruyan belum dilakukan secara } \\
\text { optimal. }\end{array}$ & 0,083 & 1 & 0,083 \\
\hline & Jumlah & $\mathbf{0 , 3 3 3}$ & & $\mathbf{0 , 5 8 3}$ \\
\hline & Total (Kekuatan + Kelemahan) & 0,617 & & 1,834 \\
\hline
\end{tabular}

Lampiran 2. Tabel Analisis EFAS

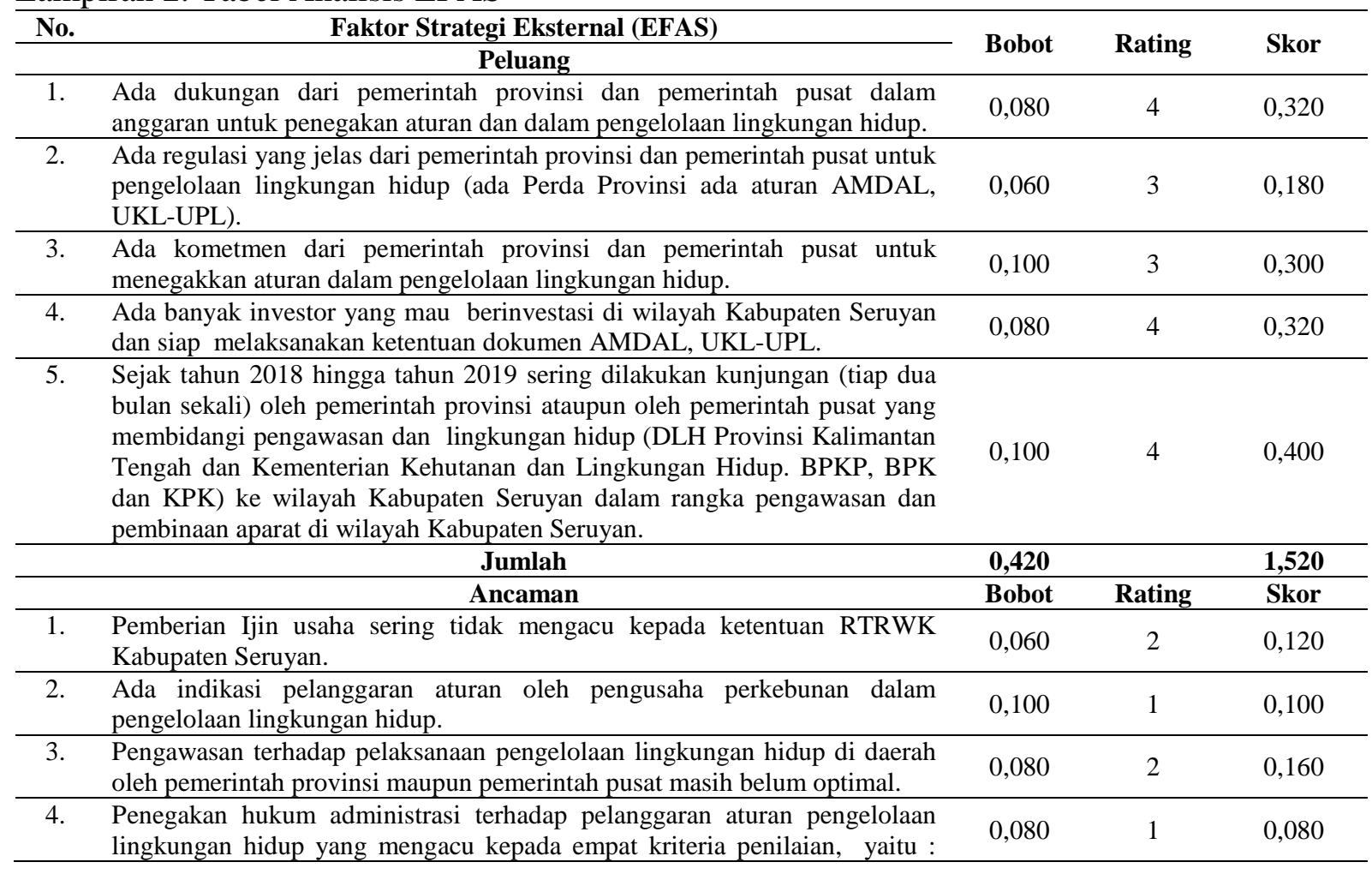


berhentinya pelanggaran; akibat yang membahayakan telah dikembalikan seperti keadaan semula; tidak mengulangi perbuatannya; dan perubahan perilaku dari pelaku pelanggaran belum efektif dilakukan.

5. Partisipasi publik, transparansi, dan demokratisasi dalam menegakkan kebijakan tentang pengelolaan sumberdaya alam dan lingkungan sangat kurang.

\begin{tabular}{cccc} 
Jumlah & $\mathbf{0 , 4 0 0}$ & $\mathbf{0 , 6 2 0}$ \\
\hline Total (Peluang + Ancaman) & \multirow{20.820}{2,140}{} \\
\hline
\end{tabular}

\section{Lampiran 3. Tabel Analisis Strategi SWOT}

\begin{tabular}{|c|c|c|}
\hline IFAS & Strengths $(S)$ & Weakness (W) \\
\hline & $\begin{array}{l}\text { 1. Pemerintah Seruyan sudah } \\
\text { memiliki perangkat SKPD yang } \\
\text { lengkap untuk menjalankan roda } \\
\text { pemerintahan dan penegakan aturan } \\
\text { perundang-undangan. }\end{array}$ & $\begin{array}{l}\text { 1. Belum dilakukan inventarisasi potensi } \\
\text { dan kerusakan lingkungan hidup pada } \\
\text { ekosistem darat dan ekosistem perairan }\end{array}$ \\
\hline & $\begin{array}{l}\text { 2. Sudah sering melakukan koordinasi } \\
\text { antar SKPD dan dunia usaha dalam } \\
\text { pengelolaan lingkungan }\end{array}$ & $\begin{array}{l}\text { 2. Belum dilakukan penetapan Ekoregion } \\
\text { di wilayah Kabupaten Seruyan. } \\
\text { (Ekoregion adalah wilayah geografis } \\
\text { yang memiliki kesamaan ciri iklim, } \\
\text { tanah, air, flora, dan fauna asli, serta } \\
\text { pola interaksi manusia dengan alam } \\
\text { yang menggambarkan integritas sistem } \\
\text { alam dan lingkungan hidup (UU No. } \\
\text { 32Tahun 2009). }\end{array}$ \\
\hline & $\begin{array}{l}\text { 3. Sudah memilki aturan tentang } \\
\text { kewajiban AMDAL UKL dan UPL. }\end{array}$ & $\begin{array}{l}\text { 3. Belum pernah melakukan kegiatan } \\
\text { bimbingan teknis tentang Tata Ruang } \\
\text { dan KLHS bagi SKPD di lingkup } \\
\text { pemerintah Kabupaten Seruyan }\end{array}$ \\
\hline & $\begin{array}{l}\text { 4. Sudah pernah menerbitkan Surat } \\
\text { Ijin lingkungan sebanyak } 19 \text { buah } \\
\text { (swasta } 7 \text { buah, pemerintah } 7 \text { buah, } \\
\text { dan koperasi } 5 \text { buah). }\end{array}$ & $\begin{array}{l}\text { 4. Belum memiliki Perda RTRWK dan } \\
\text { dokumen KLHS serta belum memiliki } \\
\text { Rencana Detail Tata Ruang (RDTR) } \\
\text { dan Bagian Wilayah Perencanaan } \\
\text { (BWP). }\end{array}$ \\
\hline EFAS & $\begin{array}{l}\text { 5. Kabupaten Seruyan memliki potensi } \\
\text { sumberdaya alam di berbagai sektor } \\
\text { perekonomian (potensi lahan untuk } \\
\text { perkebunan, potensi tambang biji } \\
\text { besi, dan pasir kuarsa, potensi } \\
\text { perairan dan perikanan, potensi } \\
\text { burung wallet, dan lain-lain. }\end{array}$ & $\begin{array}{l}\text { 5. Koordinasi antar sektor yang terlibat } \\
\text { dalam pengelolaan sumberdaya alam } \\
\text { dan lingkungan di wilayah Kabupaten } \\
\text { Seruyan belum dilakukan secara } \\
\text { optimal. }\end{array}$ \\
\hline Opportunities (O) & STRATEGI S-O & STRATEGI W-O \\
\hline $\begin{array}{l}\text { 1. Ada dukungan dari pemerintah provinsi } \\
\text { dan pemerintah pusat dalam anggaran } \\
\text { untuk penegakan aturan dan dalam } \\
\text { pengelolaan lingkungan hidup. }\end{array}$ & $\begin{array}{l}\text { 1. Memperkuat koordinasi dan } \\
\text { optimalisasi peran dan fungsi SKPD } \\
\text { dalam pengelolaan lingkungan } \\
\text { serta mempertegas penerapan sangsi } \\
\text { pelanggaran aturan dan penegakan } \\
\text { hukum. }\end{array}$ & $\begin{array}{l}\text { 1. Segera menyusun rencana dan } \\
\text { melakukan inventarisasi potensi dan } \\
\text { kerusakan lingkungan hidup pada } \\
\text { ekosistem darat dan ekosistem perairan } \\
\text { di wilayah kebupaten Seruyan. }\end{array}$ \\
\hline $\begin{array}{l}\text { 2. Ada regulasi yang jelas dari pemerintah } \\
\text { provinsi dan pemerintah pusat untuk } \\
\text { pengelolaan lingkungan hidup (ada } \\
\text { Perda Provinsi ada aturan AMDAL, } \\
\text { UKL-UPL). }\end{array}$ & $\begin{array}{l}\text { 2. Komitment dalam melaksanakan } \\
\text { hasil koordinasi dan penerapan } \\
\text { regulasi dalam pengelolaan } \\
\text { lingkungan. }\end{array}$ & $\begin{array}{l}\text { 2. Segera dilakukan penetapan Ekoregion } \\
\text { di wilayah Kabupaten Seruyan dengan } \\
\text { mengacu kepada regulasi yang ada. }\end{array}$ \\
\hline $\begin{array}{l}\text { 1. Ada komitmen dari pemerintah provinsi } \\
\text { dan pemerintah pusat untuk menegakkan } \\
\text { aturan dalam pengelolaan lingkungan } \\
\text { hidup. }\end{array}$ & $\begin{array}{l}\text { 3. Fasilitasi investasi dan optimalisasi } \\
\text { pelayanan tanpa ada bargaining } \\
\text { dalam penegakan aturan }\end{array}$ & $\begin{array}{l}\text { 3. Melakukan kegiatan bimbingan teknis } \\
\text { tentang Tata Ruang dan KLHS bagi } \\
\text { SKPD di lingkup pemerintah } \\
\text { Kabupaten Seruyan }\end{array}$ \\
\hline $\begin{array}{l}\text { 3. Ada banyak investor yang mau } \\
\text { berinvestasi di wilayah Kabupaten } \\
\text { Seruyan dan siap melaksanakan } \\
\text { ketentuan dokumen AMDAL, UKL- } \\
\text { UPL. }\end{array}$ & $\begin{array}{l}\text { 4. Tindak lanjut hasil pengawasan dan } \\
\text { kunjungan instasi propinsi dan pusat } \\
\text { dalam perbaikan pengelolaan } \\
\text { lingkungan }\end{array}$ & $\begin{array}{l}\text { 4. Implementasi kebijakan RTRWK, } \\
\text { KLHS dan melakukan penyusunan } \\
\text { RDTR pada masing-masing BWP di } \\
\text { Kabupaten Seruyan. }\end{array}$ \\
\hline $\begin{array}{l}\text { 2. Sejak tahun } 2018 \text { hingga tahun } 2019 \\
\text { sering dilakukan kunjungan (tiap dua } \\
\text { bulan sekali) oleh pemerintah provinsi } \\
\text { ataupun oleh pemerintah pusat yang } \\
\text { membidangi pengawasan ran } \\
\text { lingkungan hidup (DLH Provinsi }\end{array}$ & $\begin{array}{l}\text { 5. Penyusunan laporan dan tindak } \\
\text { lanjut hasil kunjungan instansi } \\
\text { pengawasan tingkat pusat dan } \\
\text { tingkat provinsi untuk optimalisasi } \\
\text { pelaksanaan pengelolaan } \\
\text { lingkungan di berbagai ekosistem di }\end{array}$ & $\begin{array}{l}\text { 5. Pengendalian pencemaran lingkungan } \\
\text { hidup, bertujuan untuk mengurangi } \\
\text { kemerosotan mutu dan fungsi } \\
\text { lingkungan hidup perairan darat dan } \\
\text { laut, tanah, dan udara yang disebabkan } \\
\text { oleh makin meningkatnya kegiatan }\end{array}$ \\
\hline
\end{tabular}




\begin{tabular}{|c|c|c|c|}
\hline & $\begin{array}{l}\text { Kalimantan Tengah dan Kementerian } \\
\text { Kehutanan dan Lingkungan Hidup. } \\
\text { BPKP, BPK dan KPK) ke wilayah } \\
\text { Kabupaten Seruyan dalam rangka } \\
\text { pengawasan dan pembinaan aparat di } \\
\text { wilayah Kabupaten Seruyan. }\end{array}$ & wilayah Kabupaten Seruyan. & pembangunan. \\
\hline & Threat (T) & STRATEGI S-T & STRATEGI W-T \\
\hline & $\begin{array}{l}\text { Pemberian Ijin usaha sering tidak } \\
\text { mengacu kepada ketentuan RTRWK } \\
\text { Kabupaten Seruyan. }\end{array}$ & $\begin{array}{l}\text { 1. SKPD terkait harus komitmen dalam } \\
\text { ketaatan aturan termasuk } \\
\text { memperhatikan ketentuan RTRWK } \\
\text { untuk pemberian izin investasi di } \\
\text { wilayah Kabupaten Seruyan. }\end{array}$ & $\begin{array}{l}\text { 1. Penetapan Baku Mutu lingkungan } \\
\text { hidup (Environmental quality standart) } \\
\text { dilakukan dengan mengacu kepada } \\
\text { Kriteia Baku Mutu Lingkungan Hidup } \\
\text { tingkat nasional, tingkat provinsi dan } \\
\text { disesuaikan dengan kriteria/kondisi } \\
\text { tingkat kabupaten yang selanjutnya } \\
\text { ditetapkan dengan Peraturan Daerah } \\
\text { Kabupaten Seruyan. }\end{array}$ \\
\hline 2. & $\begin{array}{l}\text { Ada indikasi pelanggaran aturan oleh } \\
\text { pengusaha perkebunan dalam } \\
\text { pengelolaan lingkungan hidup. }\end{array}$ & $\begin{array}{l}\text { 2. Instansi pengawasan harus } \\
\text { melakukan kegiatan pengawasan } \\
\text { secara ketat dengan penerapan } \\
\text { sangsi yang tegas kepada pelanggar } \\
\text { aturan. }\end{array}$ & $\begin{array}{llr}\text { 2. } & \text { Supremasi hukum } & \text { terhadap } \\
\text { pelanggaran aturan pengelolaan } & \text { and hidup harus dilakukan } \\
& \text { lingkungan hidup } \\
& \text { secara jelas dan nyata. }\end{array}$ \\
\hline 3. & $\begin{array}{l}\text { Pengawasan terhadap pelaksanaan } \\
\text { pengelolaan lingkungan hidup termasuk } \\
\text { pengendalian pencemaran lingkungan } \\
\text { hidup di daerah oleh pemerintah provinsi } \\
\text { maupun pemerintah pusat masih belum } \\
\text { optimal. }\end{array}$ & $\begin{array}{l}\text { 3. Optimalisasi pengendalian } \\
\text { pencemaran lingkungan hidupuntuk } \\
\text { mengurangi kemerosotan mutu dan } \\
\text { fungsi lingkungan hidup perairan } \\
\text { darat dan laut, tanah, dan udara yang } \\
\text { disebabkan oleh makin } \\
\text { meningkatnya ragatan } \\
\text { pembangunan. }\end{array}$ & $\begin{array}{l}\text { 3. Peningkatan aktivitas pengawasan oleh } \\
\text { instasi terkait terhadap kegiatan } \\
\text { pengelolaan lingkungan hidup oleh } \\
\text { sektor swasta dan pemerintah di } \\
\text { wilayah Kabupaten Seruyan harus } \\
\text { lebih efektif dilakukan. }\end{array}$ \\
\hline 4. & $\begin{array}{l}\text { Penegakan hukum administrasi terhadap } \\
\text { pelanggaran aturan pengelolaan } \\
\text { lingkungan hidup yang mengacu kepada } \\
\text { empat kriteria penilaian, yaitu : (1) } \\
\text { berhentinya pelanggaran; (2) akibat yang } \\
\text { membahayakan telah dikembalikan } \\
\text { seperti keadaan semula; (3) tidak } \\
\text { mengulangi perbuatannya; dan (4) } \\
\text { perubahan perilaku dari pelaku } \\
\text { pelanggaran belum efektif dilakukan. }\end{array}$ & $\begin{array}{l}\text { 4. Penerapan sanksi hukum baik berupa } \\
\text { sangsi administrasi maupun sangsi } \\
\text { pidana wajib diterapkan bagi } \\
\text { pelanggar aturan dalam pengelolaan } \\
\text { lingkungan }\end{array}$ & $\begin{array}{l}\text { 4. Penguatan kelembagaan melalui } \\
\text { alokasi pendanaan, pendidikan dan } \\
\text { pelatihan dalam upaya peningkatan } \\
\text { kualitas sumberdaya manusia untuk } \\
\text { pengelolaan lingkungan hidup di } \\
\text { wilayah Kabupaten Seruyan }\end{array}$ \\
\hline 5. & $\begin{array}{l}\text { Partisipasi publik, transparansi, dan } \\
\text { demokratisasi dalam menegakkan } \\
\text { kebijakan tentang pengelolaan } \\
\text { sumberdaya alam dan lingkungan sangat } \\
\text { kurang. }\end{array}$ & $\begin{array}{l}\text { 5. Optimalisasi kegiatan penyuluhan } \\
\text { dan pelibatan masyarakat dalam } \\
\text { pengawasan pengelolaan lingkungan } \\
\text { di wilayah Kabupaten Seruyan. }\end{array}$ & $\begin{array}{l}\text { 5. Peningkatan peran serta masyarakat } \\
\text { dan dunia usaha dalam upaya } \\
\text { pengelolaan sumberdaya alam dan } \\
\text { lingkungan hidup melalui pola } \\
\text { kemitraan. }\end{array}$ \\
\hline
\end{tabular}

